\title{
SYNTHESIS, CHARACTERIZATION AND ELECTROCHEMISTRY OF PHENYLIMIDO-RHENIUM(V) COMPLEX OF 1,4,7-TRIAZACYCLONONANE (TACN)
}

\author{
WAI-HONG FUNG, WING-CHI CHENG, SHIE-MING PENG* AND \\ CHI-MING CHE $\dagger$
}

Department of Chemistry, The University of Hong Kong, Pokfulam Road, Hong Kong

(Received 5 October 1994; accepted 18 November 1994)

\begin{abstract}
The complex $\left[\operatorname{Re}(\mathrm{NPh})(\mathrm{OH})\left(\mathrm{PPh}_{3}\right)(\mathrm{tacn})\right]^{2+}$ (1) was prepared by reacting $\left[\mathrm{Re}(\mathrm{NPh}) \mathrm{Cl}_{3}\left(\mathrm{PPh}_{3}\right)_{2}\right]$ with tacn (tacn $=1,4,7$-triazacyclononane) in $\mathrm{CH}_{2} \mathrm{Cl}_{2}$ and has been characterized by X-ray crystal analysis. The $\mathrm{Re} \equiv \mathrm{NPh}$ distance is $1.706(10) \AA$ and the $\mathrm{Re}-\mathrm{N}-\mathrm{Ph}$ angle is $170.2(9)^{\circ}$. In acetonitrile, the cyclic voltammogram of 1 shows an irreversible reduction wave at $-0.77 \mathrm{~V}$ assignable to the reduction of rhenium(V) to rhenium(IV). Complex 1 catalyses alkene oxidation by PhIO.
\end{abstract}

High valent rhenium and ruthenium complexes having metal-ligand multiple bonds have been shown to exhibit interesting electrochemical and photochemical properties ${ }^{1-3}$ and catalytic activities. ${ }^{4.5}$ Of particular interest to us are rheniumimido complexes containing facially coordinating tridentate ligands such as 1,4,7-triazacyclononane (tacn) and its methylated derivatives $\left(\mathrm{Me}_{3} \mathrm{tacn}\right)$. This paper describes the synthesis and properties of $\left[\operatorname{Re}^{\mathrm{v}}(\mathrm{NPh})(\mathrm{OH})\left(\mathrm{PPh}_{3}\right)(\mathrm{tacn})\right]^{2+}$. This complex has been found to mediate alkene oxidation by $\mathrm{PhIO}$ at room temperature.

\section{EXPERIMENTAL}

\section{Materials}

All preparations were performed using standard Schlenk or vacuum-line techniques. Dichloromethane (AR, Ajax) was distilled over calcium hydride under a nitrogen atmosphere. Organic substrates were purified by repeated distillation or recrystallization. 1,4,7-Triazacyclononane ( $\operatorname{tacn})$

\footnotetext{
* Department of Chemistry, National Taiwan University, Taipei, Taiwan.

$\dagger$ Author to whom correspondence should be addressed.
}

and $\left[\mathrm{Re}^{\mathrm{v}}(\mathrm{NPh}) \mathrm{Cl}_{3}\left(\mathrm{PPh}_{3}\right)_{2}\right]$ were prepared by published procedures. ${ }^{6.7}$

Preparation of $\left[\operatorname{Re}^{\mathrm{V}}(\mathrm{NPh})(\mathrm{OH})\left(\mathrm{PPh}_{3}\right)(\mathrm{tacn})\right]$ $\left(\mathrm{ClO}_{4}\right)_{2}$ (1). A mixture of [rhenium(V)(NPh) $\left.\mathrm{Cl}_{3}\left(\mathrm{PPh}_{3}\right)_{2}\right](0.2 \mathrm{~g}, 0.2 \mathrm{mmol})$ and tacn $(0.05$ $\mathrm{g}, 0.4 \mathrm{mmol})$ in dried $\mathrm{CH}_{2} \mathrm{Cl}_{2}\left(50 \mathrm{~cm}^{3}\right)$ was stirred under nitrogen for $24 \mathrm{~h}$ and a green solution was obtained. The solution was evaporated to dryness and the residue was dissolved in water to give a green solution. Upon addition of excess $\mathrm{LiClO}_{4}$, a green solid precipitated. The solid was recrystallized by vapour diffusion of diethyl ether into an acetonitrile solution to give green crystals (yield $50 \%$ ). Found: C, 39.5; H, 4.1; N, 6.1. Calculated for $\mathrm{C}_{30} \mathrm{H}_{36} \mathrm{~N}_{4} \mathrm{Cl}_{2} \mathrm{O}_{9} \mathrm{PRe}: \mathrm{C}, 40.7 ; \mathrm{H}, 4.1 ; \mathrm{N}, 6.3 .270$ $\mathrm{MHz}{ }^{1} \mathrm{H}$ NMR $\left(\mathrm{CD}_{3} \mathrm{CN}\right): 2.83(\mathrm{~m}, 3 \mathrm{H}), 2.95-3.40$ (m, 7H), 3.69, 3.95 (m, 1H each) $\mathrm{CH} H ; 7.28,7.83$ (br, s, 1H each) NH; $7.36(t, 2 \mathrm{H}), 7.76(\mathrm{t}, 1 \mathrm{H})$ $\mathrm{PhN} ; 7.39-7.66(\mathrm{~m}, 18 \mathrm{H}) \mathrm{PPh}_{3}, \mathrm{PhN}, \mathrm{NH} ; 11.37$ (d, $1 \mathrm{H}) \mathrm{OH} .{ }^{31} \mathrm{P}$ NMR $\left(\mathrm{CD}_{3} \mathrm{CN}\right): 1.72(\mathrm{~s}), \mathrm{PPh}_{3}$.

IR (Nujol mull) : $1140 \mathrm{~cm}^{-1}\left(v_{\mathrm{R}} \equiv \mathrm{NPh}\right)$. UV$\operatorname{vis}\left[\lambda_{\max } / \mathrm{nm}\left(\varepsilon / \mathrm{mol}^{-1} \mathrm{dm}^{3} \mathrm{~cm}^{-1}\right)\right]: 259$ (52870), 338 (22070).

Physical measurements. UV-vis absorption spectra were recorded in a Perkin-Elmer Lambda 19 spectrophotometer, IR spectra as Nujol mulls on a Nicolet 20FXC TF9IR spectrophotometer and ${ }^{1} \mathrm{H}$ NMR spectra on a JOEL $270 \mathrm{MHz}$ FTNMR spectrometer. Cyclic voltammetry was perfo:med with a Princeton Applied Research (PAR) model 
175 universal programmer and a model 173 potentiostat. $\mathrm{A} \mathrm{Ag}^{+}-\mathrm{Ag}$ reference electrode in acetonitrile was used.

GLC analyses were done on a Hewlett Packard model HP 5890 series II chromatography equipped with a flame ionization detector. Quantification of gas chromatographic components was performed on a Hewlett Packard HP 3393 series II integrator. Capillary column model HP 17 (phenyl methyl crosslink) was used to analyse the oxidation products.

Oxidation of alkene by iodosylbenzene catalysed by 1. In a typical experiment, a mixture of alkene $(0.1 \mathrm{~g})$ and $[1]\left(\mathrm{ClO}_{4}\right)_{2}(25 \mathrm{mg})$ in dichloromethane $\left(10 \mathrm{~cm}^{3}\right)$ was stirred under a nitrogen atmosphere at room temperature. Iodosylbenzene $(0.1 \mathrm{~g})$ was added to the mixture, which was then stirred for 8 $12 \mathrm{~h}$. A blank containing the same amount of solvent, substrate and iodosylbenzene but without the metal catalyst was simultaneously stirred under the same conditions. After addition of internal standard, the aliquot was analysed by GLC, and the product yields were calculated based on the amount of iodobenzene formed.

$X$-ray structure determinations - crystal data. $\left[\operatorname{Re}^{\mathrm{v}}(\mathrm{NPh})(\mathrm{OH})\left(\mathrm{PPh}_{3}\right)(\mathrm{tacn})\right]\left(\mathrm{ClO}_{4}\right)_{2} \cdot 0.5 \mathrm{Et}_{2} \mathrm{O} \cdot$ $0.5 \mathrm{CH}_{3} \mathrm{CN}, \quad \mathrm{C}_{33} \mathrm{H}_{41} \mathrm{~N}_{4.5} \mathrm{Cl}_{2} \mathrm{O}_{9.5} \mathrm{PRe}, \quad M_{\mathrm{r}}=940.8$, space group, triclinic $P \overline{1}, \quad a=10.596(6)$, $b=13.225(5), \quad c=16.028(6) \quad \AA, \quad \alpha=66.44(3)^{\circ}$, $\beta=81.41(4)^{\circ}, \gamma=69.54(4)^{\circ}, U=1928.9(14) \AA^{3}$, $Z=2, \quad D_{\mathrm{c}}=1.620 \mathrm{~g} \mathrm{~cm}^{-3}, \mu(\mathrm{Mo}-K \alpha)=34.47$ $\mathrm{cm}^{-1}, F(000)=941$.
Intensities were collected at $298 \mathrm{~K}$ on a Nonius CAD4 diffractometer with graphite-monochromatized Mo- $K \alpha$ radiation $(\gamma=0.70930 \AA)$ using the $\theta / 2 \theta$ scan mode with $2 \theta_{\max }=45^{\circ}$. Intensity data $\left(2 \theta_{\max }=45^{\circ}, h-10-11, k 0-14, l-15-17\right)$ were corrected for Lorentz and polarization effects and empirical absorption. A total of 5021 independent reflections were measured of which 4170 reflections with $I_{0}>2.0 \sigma\left(I_{0}\right)$ were used. The structure was solved by the Patterson method and refined by least squares. All data reduction and structure refinement were performed using the NRCC-SDPVAX packages. The non-hydrogen atoms were refined with anisotropic thermal parameters, and hydrogen atoms were included at idealized positions with a fixed contribution. The final $R_{\mathrm{F}}$ and $R_{\mathrm{W}}$ values are 0.056 and 0.052 , respectively. The goodness of fit is 2.76 .

Selected bond distances and bond angles are listed in Table 1.

Additional material available from the Cambridge Crystallographic Data Centre comprises coordinates, thermal parameters and remaining bond lengths and angles.

\section{RESULTS AND DISCUSSION}

High valent rhenium complexes of macrocyclic amines are not unprecedented in the literature. With tacn and its methylated derivatives, Wieghardt and co-workers had reported the synthesis and structure of $\left[\operatorname{Re}(\operatorname{tacn}) \mathrm{O}_{3}\right]^{+}, \quad\left[\operatorname{Re}\left(\mathrm{Me}_{3} \operatorname{tacn}\right) \mathrm{O}_{3}\right]^{+}$

Table 1. Selected bond distances $(\AA)$ and angles $\left(^{\circ}\right)$ of $\left[\operatorname{Re}^{\mathrm{v}}(\mathrm{NPh})(\mathrm{OH})\right.$ $\left.\left(\mathrm{PPh}_{3}\right)(\operatorname{tacn})\right]^{+}$

\begin{tabular}{lc}
\hline $\mathrm{Re}-\mathrm{P}$ & $2.434(3)$ \\
$\mathrm{Re}-\mathrm{O}(1)$ & $2.004(7)$ \\
$\mathrm{Re}-\mathrm{N}(1)$ & $1.706(10)$ \\
$\mathrm{Re}-\mathrm{N}(2)$ & $2.136(10)$ \\
$\mathrm{Re}-\mathrm{N}(3)$ & $2.203(9)$ \\
$\mathrm{Re}-\mathrm{N}(4)$ & $2.196(10)$ \\
& \\
$\mathrm{P}-\mathrm{Re}-\mathrm{O}(1)$ & $90.59(4)$ \\
$\mathrm{P}-\mathrm{Re}-\mathrm{N}(1)$ & $88.5(3)$ \\
$\mathrm{P}-\mathrm{Re}-\mathrm{N}(2)$ & $165.8(3)$ \\
$\mathrm{P}-\mathrm{Re}-\mathrm{N}(3)$ & $91.2(3)$ \\
$\mathrm{P}-\mathrm{Re}-\mathrm{N}(4)$ & $105.4(3)$ \\
$\mathrm{O}(1)-\mathrm{Re}-\mathrm{N}(1)$ & $106.9(4)$ \\
$\mathrm{O}(1)-\mathrm{Re}-\mathrm{N}(2)$ & $82.0(3)$ \\
$\mathrm{O}(1)-\mathrm{Re}-\mathrm{N}(3)$ & $88.1(3)$ \\
$\mathrm{O}(1)-\mathrm{Re}-\mathrm{N}(4)$ & $156.2(4)$ \\
$\mathrm{N}(1)-\mathrm{Re}-\mathrm{N}(2)$ & $105.2(4)$ \\
$\mathrm{N}(1)-\mathrm{Re}-\mathrm{N}(3)$ & $165.0(4)$ \\
$\mathrm{N}(1)-\mathrm{Re}-\mathrm{N}(4)$ & $91.4(4)$ \\
$\mathrm{N}(2)-\mathrm{Re}-\mathrm{N}(3)$ & $76.5(3)$
\end{tabular}

$\begin{array}{lr}\mathrm{N}(2)-\mathrm{Re}-\mathrm{N}(4) & 78.5(4) \\ \mathrm{N}(3)-\mathrm{Re}-\mathrm{N}(4) & 74.2(4) \\ \mathrm{Re}-\mathrm{P}-\mathrm{C}(13) & 111.9(4) \\ \mathrm{Re}-\mathrm{P}-\mathrm{C}(19) & 112.9(4) \\ \mathrm{Re}-\mathrm{P}-\mathrm{C}(25) & 116.5(4) \\ \mathrm{Re}-\mathrm{N}(1)-\mathrm{C}(7) & 170.2(9) \\ \mathrm{Re}-\mathrm{N}(2)-\mathrm{C}(1) & 110.8(7) \\ \mathrm{Re}-\mathrm{N}(2)-\mathrm{C}(6) & 114.2(7) \\ \mathrm{Re}-\mathrm{N}(3)-\mathrm{C}(2) & 112.9(7) \\ \mathrm{Re}-\mathrm{N}(3)-\mathrm{C}(3) & 110.6(7) \\ \mathrm{Re}-\mathrm{N}(4)-\mathrm{C}(4) & 116.2(7) \\ \mathrm{Re}-\mathrm{N}(4)-\mathrm{C}(5) & 103.5(7)\end{array}$


$\left(\mathrm{Me}_{3} \mathrm{tacn}=1,4,7\right.$-trimethyl-1,4,7-triazacyclononane) and some monomeric and dimeric rhenium(V) complexes. ${ }^{8,9}$ In a previous study, the synthesis and $\mathrm{X}$-ray structure of trans-[Re(NPh) $(\mathrm{OH})(\mathrm{cyclam})]^{2+}$ was also reported. ${ }^{3 a}$ In this work, compound 1 was prepared by reacting $\operatorname{Re}(\mathrm{NPh})$ $\mathrm{Cl}_{3}\left(\mathrm{PPh}_{3}\right)_{2}$ with tacn in $\mathrm{CH}_{2} \mathrm{Cl}_{2}$ under dry nitrogen. When oxygen was present during the reaction, the product yield was significantly reduced and a significant amount of $\left[\mathrm{ReO}_{3}(\mathrm{tacn})\right]^{+}$was isolated as a perchlorate salt. $[1]\left(\mathrm{ClO}_{4}\right)_{2}$ is diamagnetic and is stable in water and acetonitrile at room temperature.

A perspective view of $\mathbf{1}$ is shown in Fig. 1. The structure features an interesting rhenium(V) complex having a phenylimido and a hydroxy group cis to each other. As expected, tacn facially coordinates to rhenium(V) with the $\mathrm{N}(3)$ atom trans to the phenylimido moiety. The $\mathrm{Re} \equiv \mathrm{NPh}$ distance of $1.706(10) \AA$, is shorter than the related value of $1.731(9) \quad \AA$ in trans-[Re $(\mathrm{NPh})(\mathrm{OH})($ cyclam $)]$ $\left.\mathrm{ClO}_{4}\right)_{2}{ }^{3 \mathrm{a}}$ and of $1.740(6) \AA$ in $\left[\mathrm{Re}(\mathrm{NPh})(\mathrm{bpy})_{2}\right.$ $(\mathrm{OEt})]\left(\mathrm{PF}_{6}\right)_{2} \cdot{ }^{1 \mathrm{~b}}$ It is, however, similar to the $\mathrm{Re} \equiv \mathrm{N}^{\mathrm{B}} \mathrm{Bu}$ distance of $1.709(3) \AA$ found in $\mathrm{Re}\left(\mathrm{N}^{\prime} \mathrm{Bu}\right) \mathrm{Cl}_{2}\left(\eta^{5}-\mathrm{C}_{5} \mathrm{Me}_{5}\right)_{2} \cdot{ }^{10}$ The approximate linearity of the $\mathrm{Re}-\mathrm{N}-\mathrm{Ph}$ unit $\left(170.2(9)^{\circ}\right)$ indicates that the phenylimido group acts as a six-electron donor. The $\mathrm{Re}-\mathrm{N}(\mathrm{tacn})$ distances are not equivalent. The $\mathrm{Re}-\mathrm{N}(3)$ and $\mathrm{Re}-\mathrm{N}(4)$ (bonds with the $\mathrm{N}$ atoms trans to a $\pi$-donor) have longer distance than that of $\mathrm{Re}-\mathrm{N}(2)$ which is trans to $\mathrm{PPh}_{3}$.

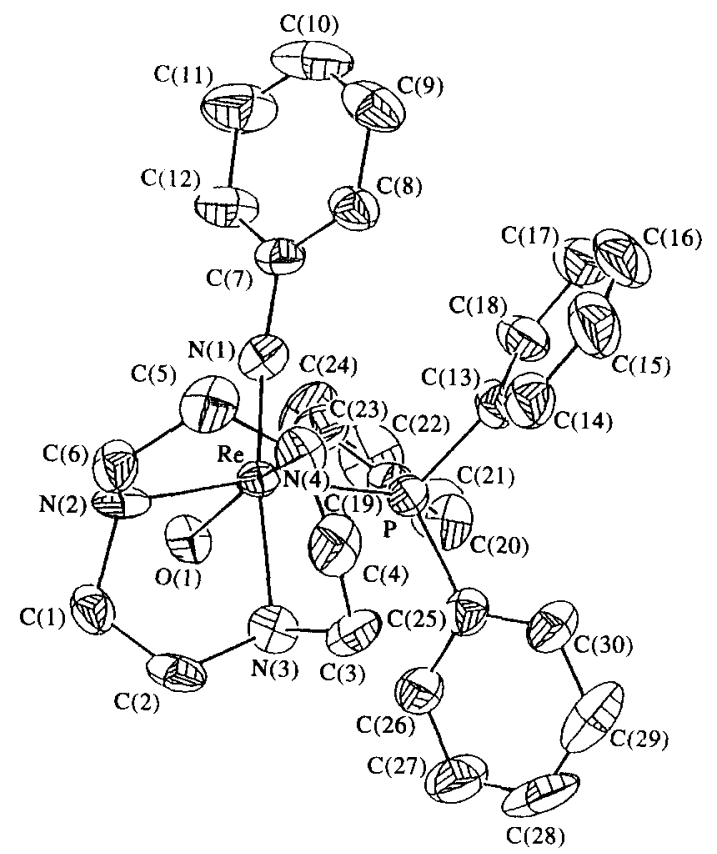

Fig. 1. A perspective view of the $[\operatorname{Re}(\mathrm{NPh})(\mathrm{OH})$ $\left.\left(\mathrm{PPh}_{3}\right)(\mathrm{tacn})\right]^{2+}$ cation.
The $\mathrm{Re}-\mathrm{O}(1)$ distance of $2.004(7) \AA$ indicates some multiple bond character. The $\mathrm{N}(1)-\mathrm{O}(1)$ angle of $106.9(4)^{\prime \prime}$ is smaller than the $\mathrm{O}-\mathrm{Re}-\mathrm{O}$ angle of $121.4(4)^{\circ}$ in $c i s-\left[\operatorname{Re}^{\mathrm{v}}(\text { bpy }) \mathrm{py}_{2} \mathrm{O}_{2}\right]^{+11}$ (py $=$ pyridine).

The UV-vis absorption spectrum of $\mathbf{1}$ in acetonitrile shows two intense absorption peaks at 259 and $338 \mathrm{~nm}$, which are due to dipole-allowed transitions because of their large $\varepsilon_{\max }$ values. It is interesting to note that the $338 \mathrm{~nm}$ band is similarly present in other $\mathrm{Re}^{v} \mathrm{~N} \equiv \mathrm{Ph}$ complexes such as trans-[Re $\left.(\text { dppe })_{2}(\mathrm{NPh}) \mathrm{Cl}\right]^{2+} \quad\left(\lambda_{\max }=339 \mathrm{~nm}\right)^{1 \mathrm{~h}}$ and trans- $[\operatorname{Re}(\mathrm{NPh})(\mathrm{OH})(\mathrm{cyclam})]^{2+} \quad\left(\lambda_{\max }=308\right.$ $\mathrm{nm}){ }^{3 \mathrm{~b}}$ The 'H NMR spectrum for $\left[\operatorname{Re}(\mathrm{NPh})(\mathrm{OH})\left(\mathrm{PPh}_{3}\right)(\operatorname{tacn})\right]\left(\mathrm{ClO}_{4}\right)_{2}$ in $\mathrm{CD}_{3} \mathrm{CN}$ indicates a $C_{1}$ symmetry for the cation. The result of $\mathrm{D}_{2} \mathrm{O}$ exchange experiment indicated that the $\mathrm{O}-\mathrm{H}$ and $\mathrm{N}-\mathrm{H}$ protons are exchangeable. The cyclic voltammogram of $\left[\mathrm{Re}(\mathrm{NPh})(\mathrm{OH})\left(\mathrm{PPh}_{3}\right)(\operatorname{tacn})\right]^{2+}$ in acetonitrile with $0.1 \mathrm{M}$ tetra-n-butylammonium hexafluorophosphate as supporting electrolyte shows two irreversible reduction waves at $-0.77 \mathrm{~V}$ and $-1.34 \mathrm{~V} v s$ SCE. With reference to previous electrochemical study on trans-[Re(NPh)(OH)(cyclam) $]^{2+},{ }^{3 a}$ the former wave is tentatively assigned to the reduction of rhenium(V) to rhenium(IV). Upon oxidation, an irreversible wave at $1.0 \mathrm{~V}$ is found. An electrochemical study of $[1]\left(\mathrm{ClO}_{4}\right)_{2}$ in aqueous solution is hampered by its low solubility.

\section{REACTIVITIES}

The use of high valent rhenium complexes as catalysts for alkene oxidation have been reported. ${ }^{12}$ In this work, $\left[\operatorname{Re}(\mathrm{NPh})(\mathrm{OH})\left(\mathrm{PPh}_{3}\right)(\mathrm{tacn})\right]^{2+}$ was found to mediate oxidation of alkenes by iodosylbenzene and the results are summarized in Table 2. In each reaction studied, the total yield of organic products based on the amount of $\mathrm{PhI}$ formed is $<50 \%$. This has been found to be due to the disproportionation of $\mathrm{PhIO}$ to $\mathrm{PhI}$ and $\mathrm{PhIO}_{2}$ catalysed by the rhenium complex. Figure 2 shows the time course of the PhIO oxidation of styrene catalysed by $\left[\operatorname{Re}(\mathrm{NPh})(\mathrm{OH})\left(\mathrm{PPh}_{3}\right)(\operatorname{tacn})\right]^{2+}$. The reaction was slow, and no induction period was found. Styrene was oxidized to a mixture of styrene oxide and benzaldehyde $(\mathrm{C}=\mathrm{C}$ cleavage product $)$ in a ratio of $1: 2$. In the case of cyclohexene, 2cyclohexen-1-one and 2-cyclohexen-1-ol were the predominant products. Cyclooctene was oxidized to give cyclooctene oxide only. Attempts to identify the active intermediate in these oxidation reactions failed. Addition of $\mathrm{PhIO}$ to an acetonitrile solution of $\left[\operatorname{Re}^{\mathrm{V}}(\mathrm{NPh})(\mathrm{OH})\left(\mathrm{PPh}_{3}\right)(\operatorname{tacn})\right]^{2+}$ gave no immediate spectral change. It is likely that in the catalytic oxidation reaction described above, the 
Table 2. Results of $\left[\mathrm{Re}(\mathrm{NPh})(\mathrm{OH})\left(\mathrm{PPh}_{3}\right)(\mathrm{tacn})\right]\left(\mathrm{ClO}_{4}\right)_{2}$ catalysed oxidation of alkenes by $\mathrm{PhIO}^{a}$

\begin{tabular}{|c|c|c|c|}
\hline Substrate & Solvent & Products & Turnover $^{b}$ \\
\hline Styrene & Dichloromethane & $\begin{array}{l}\text { Styrene oxide } \\
\text { Benzaldehyde }\end{array}$ & 11 \\
\hline Styrene & Acetonitrile & Benzaldehyde & Trace \\
\hline Cyclohexene & Dichloromethane & $\begin{array}{l}\text { Cyclohexene oxide } \\
\text { 2-Cyclohexen-1-ol } \\
\text { 2-Cyclohexen-1-one }\end{array}$ & 8 \\
\hline Cyclooctene & Dichloromethane & Cyclooctene oxide & 4 \\
\hline
\end{tabular}

${ }^{a}$ Conditions: alkene $(0.1 \mathrm{~g})$, PhIO $(0.1 \mathrm{~g})$, catalyst $(25 \mathrm{mg})$; time $8 \mathrm{~h}$; temperature $25^{\circ} \mathrm{C}$.

${ }^{b}$ The turnover values are based on the ratio of moles of oxidized products formed : moles of metal catalyst used.

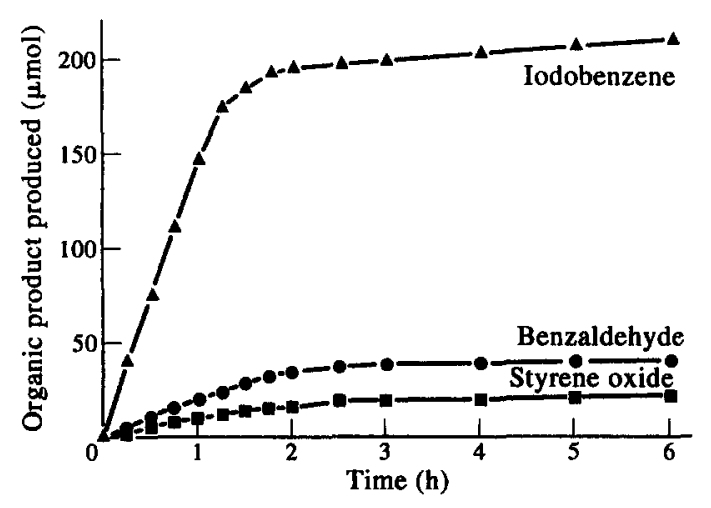

Fig. 2. Time dependence for the oxidation of styrene by iodosylbenzene catalysed by $\left[\operatorname{Re}^{\mathrm{v}}(\mathrm{NPh})(\mathrm{OH})\left(\mathrm{PPh}_{3}\right)\right.$ (tacn) $]\left(\mathrm{ClO}_{4}\right)_{2}$ in dichloromethane. Plot of amount of styrene oxide, benzaldehyde and iodobenzene $v s$ reaction time.

complex functions as a Lewis acid catalyst which activates $\mathrm{PhIO}$ through a non-redox pathway. The activation of $\mathrm{PhIO}$ by non-redox active transition metal ions like copper(II) had been previously reported by VanAtta and co-workers. ${ }^{13}$

Acknowledgements - We acknowledge support from The University of Hong Kong and The Hong Kong Research Grants Council. W.-C.C. acknowledges the receipt of a fellowship administered by the Sir Edward Youde Foundation.

\section{REFERENCES}

1. (a) G. A. Neyhart, M. Bakir, J. Boaz, W. J. Vining and B. P. Sullivan, Coord. Chem. Rev. 1991, 111, 27; (b) M. Bakir, S. Paulson, P. Goodson and B. P. Sullivan, Inorg. Chem. 1992, 31, 1127 ; (c) J. R.
Winkler and H. B. Gray, Inorg. Chem. 1985, 24, 346; (d) H. H. Thorp, C. V. Kumar, N, J., Turro and H. B. Gray, J. Am. Chem. Soc. 1989, 111, 4364 ; (c) W. Liu and H. H. Thorp, Inorg. Chem. 1994, 33, 1026.

2. (a) D. W. Pipes and T. J. Meyer, Inorg. Chem. 1986, 25, 3256; (b) M. S. Ram, L. M. Jones, H. J. Ward, Y. H. Wong, C. S. Johnson, P. Subramanian and J. T. Hupp, Inorg. Chem. 1991, 30, 2928.

3. (a) Y. P. Wang, C. M. Che, K. Y. Wong and S. M. Peng, Inorg. Chem. 1993, 32, 5827; (b) C. M. Che, Y. P. Wang, K. Y. Wong and S. M. Peng, J. Chem. Soc., Dalton Trans. 1992, 2675.

4. (a) W. A. Herrmann, R. W. Fischer and D. Marz, Angew. Chem., Int. Ed. Engl. 1991, 30, 1638; (b) W. A. Hermann, R. W. Fischer, M. U. Rauch and W. Scherer, Angew. Chem., Int. Ed. Engl. 1993, 32, 1157.

5. (a) W. C. Cheng, W. Y. Yu, K. K. Cheung and C. M. Che, J. Chem. Soc., Chem. Commun. 1994, 1063; (b) W. C. Cheng, W. Y. Yu, K., K. Cheung and C. M. Che, J. Chem. Soc., Dalton Trans. 1994, 57.

6. K. Wieghardt, W. Schmidt, H. Endres and C. R. Wolfe, Chem. Ber. 1979, 112, 2220.

7. J. Chatt, J. D. Garforth, N. P. Johnson and G. A. Rowe, J. Chem. Soc. 1964, 1012.

8. (a) K. Wieghardt, C. Pomp, B. Nuber and J. Weiss, Inorg. Chem. 1986, 25, 1659; (b) W. A. Herrmann, P. W. Roesky, F. E. Kühn, W. Scherer and M. Kleine, Angew Chem., Int. Ed. Engl. 1993, 32, 1714.

9. G. Böhn, K. Waieghardt, B. Nuber and J. Weiss, Inorg. Chem. 1991, 30, 3464.

10. W. A. Herrmann, G. Weischselbaumer, R. A. Paciwllo, R. A. Fischert, E. Herdtweck, J. Okuda and D. W. Marz, Organometallics 1990, 9, 489.

11. R. L. Blackbourn, L. M. Jones, M. S. Ram, M. Sabat and J. T. Hupp, Inorg. Chem. 1990, 29, 1791.

12. W. A. Herrmann, R. W., Fischer, M. U. Rauch and W. Scherer, J. Mol. Catal. 1994, 86, 243 and refs therein.

13. R. B. VanAtta, C. C. Franklin and J. S. Valentine, Inorg. Chem. 1984, 23, 4123. 